\title{
SPOREDNO KRIVIČNO ZAKONODAVSTVO U REPUBLICI SRBIJI
}

\author{
Dragan Jovašević \\ Univerzitet u Nišu, Pravni fakultet
}

cilju obezbeđenja i zaštite najznačajnijih društvenih dobara i vrednosti u svim savremenim državama posebno mesto, ulogu i značaj ima krivično pravo. Ono kroz sistem zakonskih propisa određuje pojedina krivična dela i sistem krivičnih sankcija u cilju suzbijanja i sprečavanja vršenja krivičnih dela. To znači da se zakon, javlja kao osnovni, formalni izvor krivičnog prava koji izvire iz ustavnih normi. Pored Krivičnog zakonika koji predstavlja kodifikovani sistem pravnih normi koje obuhvataju celokupnu oblast krivičnog prava, u mnogim državama je u primeni i sporedno, pomoćno ili dopunsko krivično pravo. To je skup zakona iz drugih oblasti pravnog života, kojima se na načelima i u okvirima Krivičnog zakonika određuju pojam i karakteristike jednog ili više krivičnih dela i to upravo dela kojima se povređuju i krše norme tih posebnih zakona. I osnovno i sporedno krivično pravo ima jedinstveno postavljeni cilj - efikasna, zakonita, blagovremena i kvalitetna zaštita društva od kriminaliteta. Upravo u ovom radu se govori o mestu, ulozi i značaju sporednog, pomoćnog ili dopunskog krivičnog prava u ostvarivanju zaštitne, garantivne funkcije (uloge) krivičnog prava uopšte.

Ključne reči: Krivični zakonik, sporedno pravo, krivično delo, sankcija, zaštitna funkcija

\section{Osnovi krivičnog prava}

Krivično pravo se može posmatrati u dvojakom smislu: 1) kao grana pozitivnog prava i 2) kao grana pravne nauke. Shvaćeno na prvi način krivično pravo je sistem zakonskih propisa (ius publicum) kojima se određuju krivična dela i krivične sankcije, kao i uslovi za njihovu primenu prema učiniocima krivičnih dela u cilju suzbijanja dela kojima se povređuju ili ugrožavaju zaštićene vrednosti ili je to skup pravnih normi koje određuju sadržaje i obim ovlašćenja države na kažnjavanje pri čemu temeljna pretpostavka za primenu tih normi predstavlja određeno ponašanje koje je propisano kao krivično delo. ${ }^{1} \mathrm{U}$ ovom značenju se krivično pravo izjednačuje sa krivičnim zakonodavstvom.

\footnotetext{
* Dr Dragan Jovašević je redovni profesor.

${ }^{1}$ P. Novoselec, Opći dio kaznenog prava, Zagreb, 2004, str. 1.
} 
Drugim rečima, krivično pravo je deo pravnog poretka koji propisuje koja se ljudska ponašanja određuju kao krivična dela i kakva je pravno organizovana reakcija prema učiniocima takvih dela. ${ }^{2}$ Krivično pravo se takođe može odrediti kao sistem propisa kojima se u jednoj državi određuje koja se ponašanja smatraju kao krivična dela i koje kazne i druge krivične sankcije i pod kojim uslovima mogu biti primenjene prema njihovim učiniocima, ${ }^{3}$ odnosno kao sistem zakonskih propisa kojima se zaštićuju osnovne vrednosti društvene zajednice na način kojim se ponašanja koja ih povređuju ili ugrožavaju određuju kao krivična dela i kojim se za njihove učinioce propisuju krivičnopravne sankcije. ${ }^{4}$ Krivično pravo kao grana pravne nauke predstavlja sistematizovani skup znanja o osnovnim pojmovima i institutima koji su propisani pozitivnim krivičnim zakonodavstvom ili je to nauka koja proučava pozitivno krivično pravo sa ciljem da sistematski izloži i protumači ove pravne propise i otkrije njihov smisao i socijalnu namenu.

Iz navedenih definicija proizilazi da pojam krivičnog prava kao grane pozitivnog prava sadrži materijalni i formalni elemenat. Materijalni elemenat, odnosno sadržinu krivičnog prava čini određivanje krivičnog dela i krivične sankcije u cilju ostvarenja zaštitne, garantivne funkcije - suzbijanja kriminaliteta kojim se povređuju ili ugrožavaju zaštićene društvene vrednosti. Formalni elemenat označava da se krivična dela i krivične sankcije, kao i uslovi za njihovu primenu određuju samo zakonom. To ukazuje da je krivično pravo zakonsko pravo, odnosno da je njegov osnovni princip - princip legaliteta ili zakonitosti krivičnog dela i kazne (član 1. Krivičnog zakonika Republike Srbije - KZ RS). Pošto je pravni poredak određen nizom zakona koji u svojoj ukupnosti čine zakonodavstvo jedne države, to ce i krivično pravo kao zakonsko pravo može posmatrati kao grana zakonodavstva, odnosno kao grana pozitivnog prava države. ${ }^{5}$

Materijalna (socijalna) karakteristika krivičnog prava sastoji se u njegovoj socijalnoj funkciji - a to je zaštita najznačajnijih društvenih dobara i vrednosti određene države. ${ }^{6} \mathrm{Ta}$ zaštita se ostvaruje propisivanjem, izricanjem i izvršenjem sankcija koje imaju prinudni karakter, a koje se primenjuju prema učiniocima krivičnih dela kojima se povređuju ili ugrožavaju zaštićene vrednosti. Krivično pravo, dakle, proglašava određena ljudska ponašanja kao krivična dela predviđajući za njihove učinioce određenu vrstu i meru kazne ili druge krivične sankcije. Iz toga proizilazi i cilj ove grane prava - uticanje na ljudsko ponašanje na posredan način propisivanjem zabranjenih i kažnjivih ponašanja čime se utiče na ljude u pogledu izbora načina ponašanja u skladu sa propisima pravnog poretka ili protiv njega. To znači da cilj krivičnog prava nije u samoj primeni kazne prema neposlušnima. ${ }^{7}$

\footnotetext{
${ }^{2}$ G. Marjanovik, Makedonsko krivično pravo, Opšt del, Skopje, 1998, str. 2.

${ }^{3}$ Ž. Horvatić, Kazneno pravo, Opći dio, Zagreb, 2003, str. 12. U pravnoj teoriji postoje i druga pojmovna definisanja krivičnog prava, pa se krivično pravo određuje i na sledeći način: kao sistem pravnih pravila kojima se u određenoj državi zaštićuju određene vrednosti (dobra ili interesi) od ponašanja kojima se te vrednosti povređuju ili ugrožavaju time što se takva ponašanja proglašavaju za krivična dela i što se propisuju krivične sankcije koje se primenjuju prema njihovim učiniocima (B. Zlatarić, Krivično pravo, Opći dio, Zagreb, 1977, str. 3); kao sistem zakonskih pravnih pravila koja propisuju pretpostavke kažnjivosti i primene sankcija koje se mogu izreći učiniocima krivičnih dela (P. Novoselec, Opći dio kaznenog prava, op. cit. str. 1-2).

${ }^{4}$ V. Grozdanić, M. Škorić, Uvod u kazneno pravo, Opći dio, Rijeka, 2009, str. 2.

${ }^{5}$ D. Jovašević, Krivično pravo, Opšti deo, Beograd, 2018, str. 4-6.

${ }^{6}$ Zadatak krivičnog prava je zaštita pravnih dobara preko zaštite osnovnih, elementarnih socijalno-etičkih vrednosti u okviru pravednosti (H. Welzel, Das Deutsche Strafrecht, Berlin,1960, str. 5).

${ }^{7}$ B. Petrović, D. Jovašević, A. Ferhatović, Krivično pravo 1, Sarajevo, 2015, str. 2-3.
} 
Krivično pravo ${ }^{8}$ naše države je deo jedinstvenog pravnog sistema, ali koje u tom sistemu ima poseban zadatak - da obezbedi zakonitu, kvalitetnu, efikasnu i blagovremenu zaštitu vrednosti, dobara i interesa predviđenih krivičnim zakonodavstvom. Na osnovu navedenih karakteristika krivično pravo naše države se može definisati kao sistem zakonskih propisa kojima se određuju krivična dela i krivične sankcije, kao i osnovi i uslovi za primenu krivičnih sankcija prema učiniocima krivičnih dela u cilju suzbijanja dela kojima se povređuju ili ugrožavaju vrednosti zaštićene krivičnim zakonodavstvom (član 4. KZ RS), a to su čovek i druge osnovne društvene vrednosti bez preciznog naznačenja u čemu se one sastoje. ${ }^{9}$

Krivično pravo kao grana pozitivnog prava se bavi određivanjem krivičnih dela i krivičnih sankcija, kao i osnova i uslova za primenu krivičnih sankcija prema učiniocima takvih dela. Prema tome, krivično delo i krivična sankcija, pojavljuju se kao osnovni pojmovi i instituti kojima se bavi krivično pravo kao grana pozitivnog prava, ali i kao grana pravne nauke.

Određivanjem krivičnih dela, krivično pravo štiti najznačajnije društvene vrednosti. Sredstva za zaštitu tih vrednosti od različitih oblika i vidova ugrožavanja ili povrede jesu krivične sankcije. Krivične sankcije imaju prinudni karakter jer se primenjuju protiv volje učinioca krivičnog dela. One se sastoje u ograničavanju ili oduzimanju učiniocu krivičnog dela prava ili sloboda koje ima kao građanin na osnovu pozitivnih pravnih propisa. Ali, da bi se sankcija mogla primeniti, moraju se utvrditi osnovi i uslovi koji opravdavaju njenu primenu. Otuda utvrđivanje osnova i uslova za primenu krivične sankcije, u prvom redu krivice, takođe čini predmet krivičnog prava. To znači da je krivično pravo pozitivna grana zakonodavstva države koja ima za predmet regulative da odredi krivično delo i krivičnu sankciju i osnove i uslove za primenu krivične sankcije, a y prvom redu krivicu kao osnova za primenu kazne.

No, krivično pravo nije samo grana zakonodavstva, već i naučna disciplina, grana pravne nauke. Kao grana nauke, krivično pravo se bavi proučavanjem pojmova i instituta koji čine predmet njegove regulative: krivičnog dela i krivične sankcije. Ovo proučavanje je neophodno kako bi se ovi pojmovi i instituti na efikasan način mogli primeniti u konkretnim slučajevima izvršenja krivičnog dela od strane jednog ili više lica. Ali krivično delo, krivična sankcija i ostali instituti krivičnog prava nisu samo pravne pojave, već su pre svega društvene pojave koje kroz pravnu formu ispoljavaju svoju sadržinu. A kao društvene pojave one su podložne promenama u razvoju društva što sve zahteva adekvatnu analizu, tumačenje i objašnjenje.

\section{Deoba krivičnog prava}

lako krivično pravo predstavlja jedinstvenu granu pozitivnog prava, ipak se zavisno od različitih kriterijuma može uočiti više deoba ove grane prava.

Osnovna je deoba krivičnog prava na: a) materijalno, b) procesno i v) izvršno. Materijalno (supstancijalno) pravo predstavlja sistem zakonskih propisa kojima se određuju pojam i karakteristike krivičnih dela, sistem krivičnih sankcija i osnovi i uslovi za utvrđivanje

\footnotetext{
${ }^{8}$ D. Jovašević, Leksikon krivičnog prava, Beograd, 2011, str. 122-123.

${ }^{9}$ Lj. Lazarević, B. Vučković, V. Vučković, Komentar Krivičnog zakonika Crne Gore, Cetinje, 2004, str. 25-26.
} 
krivice i kažnjivosti njihovih učinilaca. Ono se može manifestovati, realizovati tek posredstvom procesnog prava. Naime, krivično procesno (formalno) pravo kao sistem zakonskih propisa određuje pojam i vrste procesnih subjekata, procesna načela, arhitektoniku i tok krivičnog postupka. A izvršno krivično pravo (pravo izvršenja krivičnih sankcija) određuje postupak, način i uslove izvršenja izrečenih krivičnih sankcija od strane krivičnog suda. Materijalno krivično pravo se dalje može podeliti na: a) opšte ${ }^{10}$ i b) posebno pri čemu su ova dva dela uzajamno povezana i međusobno uslovljena. Ova deoba ima osnova u strukturi savremenih krivičnih zakona ili zakonika. Zatim krivično pravo može da bude: a) redovno - koje se primenjuje po pravilu, običajeno u doba mira, u redovnim, normalnim okolnostima i b) vanredno - koje se primenjuje u posebnim, vanrednim situacijama kao što su: ratno stanje, stanje neposredne ratne opasnosti ili oružanog sukoba. ${ }^{1}$

Zavisno od izvora krivično pravo može da bude: a) nacionalno (interno) i b) međunarodno. Izvor nacionalnog krivičnog prava jeste domaći Krivični zakonik, a izvor međunarodnog krivičnog prava jesu međunarodni pravni akti: Statut Haškog tribunala, Statut tribunala za Ruandu, Rimski statut stalnog međunarodnog krivičnog suda i dr. Krivično (nacionalno) pravo se dalje može podeliti na: a) osnovno i b) sporedno ili dopunsko.

\section{Izvori krivičnog prava}

Izvor krivičnog prava se može shvatiti dvojako: a) u formalnom i b) u materijalnom smislu. U formalnom smislu (fontes iuris cognoscendi) izvor krivičnog prava čine pravni akti (izražajni oblici) koji sadrže krivičnopravne norme kojima se društveni odnosi prinudno uređuju, bilo da se određena ponašanja zabranjuju ili da se nalažu, odnosno kojima se određuju krivična dela i krivične sankcije. U materijalnom smislu (fontes iuris essendi) izvor krivičnog prava jesu društveni odnosi regulisani putem krivičnopravnih normi. Međutim, iako se pojam izvora krivičnog prava izražava u materijalnom i formalnom smislu, obično se pod izvorom prava podrazumeva formalni izvor - pravni akti koji sadrže krivičnopravne norme.

Izvori krivičnog prava se dele na: a) osnovne (neposredne) i b) dopunske (pomoćne ili posredne) izvore. Osnovni izvori neposredno propisuju krivična dela i krivične sankcije. Osnovni (neposredni) izvor savremenog krivičnog prava, koje se zasniva na principu zakonitosti krivičnog dela i kazne, jeste krivični zakon ili zakonik. Dopunski izvori sadrže odredbe krivičnopravnog sadržaja, ali se primenjuju samo kada zakon upućuje na njihovu primenu. To su: a) normativni akti državnih organa, b) međunarodni ugovori, v) običajno pravo, g) sudska praksa i d) pravna nauka (doktrina). U našoj državi osnovni izvor krivičnog prava jeste zakon koji svoju osnovu nalazi u Ustavu Republike Srbije ${ }^{12}$ iz 2006. godine (praizvor krivičnog prava).

\footnotetext{
${ }^{10} \mathrm{U}$ pravnoj teoriji se mogu naći shvatanja prema kojima "opšte" krivično pravo znači pravo koje se odnosi na sve građane bez izuzetaka, dok je "posebno" pravo ono koje se odnosi na posebne kategorije lica: maloletnike, vojna lica (G. Marjanovik, Makedonsko krivično pravo, Opšt del, op. cit. str. 7 ili V. Grozdanić, M. Škorić, Uvod u kazneno pravo, Opći dio, op. cit. str. 5). No, uobičajeno je da opšte krivično pravo sadrži odredbe koje važe za sva krivična dela. Njima se uređuju pretpostavke kažnjivosti i krivičnih sankcija, dok posebni deo sadrži samo opise pojedinih krivičnih dela i kazne koje se mogu izreći njihovim učiniocima (P. Novoselec, Opći dio kaznenog prava, op. cit. str. 4) .

${ }^{11}$ G. Marjanovik, Makedonsko krivično pravo, Opšt del, op.cit. str. 7

${ }^{12}$ Službeni glasnik RS, br. 98/2006.
} 


\section{Osnovni izvor}

Osnovni izvor krivičnog prava u Republici Srbiji jesu zakoni. To su: 1) Krivični zakonik, ${ }^{13}$ 2) Zakon o maloletnim učiniocima krivičnih dela i krivičnopravnoj zaštiti maloletnih lica, ${ }^{14}$ 3) Zakon o odgovornosti pravnih lica za krivična dela, ${ }^{15}$ 4) Zakon o posebnim merama za sprečavanje vršenja krivičnih dela protiv polne slobode prema maloletnim licima, ${ }^{16}$ 5) Zakon o oduzimanju imovine proistekle iz krivičnog dela ${ }^{17}$ i 6) Zakon o ograničavanju raspolaganja imovinom s ciljem sprečavanja terorizma i širenja oružja za masovno uništenje. ${ }^{18}$

Pored osnovnog, postoji i dopunsko, sporedno ili pomoćno krivično pravo. Njega čini skup krivičnopravnih odredbi koje su sadržane u više desetina zakona iz drugih oblasti prava, koje propisuju krivična dela kojima se krše pravila utvrđena tim zakonima. U sporedne krivične zakone spadaju npr.: Zakon o sredstvima za zaštitu bilja, Zakon o zdravlju bilja, Zakon o genetički modifikovanim organizmima, Zakon o javnom redu i miru, Zakon o poreskom postupku i poreskoj administraciji, Zakon o sprečavanju dopinga u sportu, Zakon o tržištu hartija od vrednosti i drugih finansijskih instrumenata i dr. Skup ovih zakona predstavlja sporedno, dopunsko ili pomoćno krivično zakonodavstvo. Naziv „sporedno" ne znači da se ovde radi o malom značaju ovih propisa. Među njima ima i takvih zakona koji predviđaju teška krivična dela zaprećena strogim kaznama. Odnos odredaba iz sporednog i osnovnog krivičnog zakonodavstva je uređen tako da odredbe opšteg dela Krivičnog zakonika važe i za krivična dela predviđena u sporednim zakonima.

Krivični zakonik Republike Srbije kao osnovni izvor krivičnog prava čine dva dela: a) opšti deo (od prve do dvanaeste glave, članovi od 1-112) i 2) posebni deo (od trinaeste do trideset šeste glave, članovi od 113-432). Opšti deo Krivičnog zakonika čine sledeće glave: 1) osnovne odredbe, 2) važenje krivičnog zakonodavstva Republike Srbije, 3) krivično delo, 4) kazne, 5) mere upozorenja, 6) mere bezbednosti, 7) oduzimanje imovinske koristi, 8) pravne posledice osude, 9) rehabilitacija, prestanak pravnih posledica osude i davanje podataka iz kaznene evidencije, 10) zastarelost, 11) amnestija i pomilovanje i 12) značenje izraza. Posebni deo Krivičnog zakonika čine sledeće glave: 1) krivična dela protiv života i tela, 2) krivična dela protiv sloboda i prava čoveka i građanina, 3) krivična dela protiv izbornih prava, 4) krivična dela protiv prava po osnovu rada, 5) krivična dela protiv časti i ugleda, 6) krivična dela protiv polne slobode, 7) krivična dela protiv braka i porodice, 8) krivična dela protiv intelektualne svojine, 9) krivična dela protiv imovine, 10) krivična dela protiv privrede, 11) krivična dela protiv zdravlja ljudi, 12) krivična dela protiv životne sredine, 13) krivična dela protiv opšte sigurnosti ljudi i imovine, 14) krivična dela protiv bezbednosti javnog saobraćaja, 15) krivična dela protiv bezbednosti računarskih podataka, 16) krivična dela protiv ustavnog uređenja i bezbednosti Republike Srbije, 17) krivična dela protiv državnih organa, 18) krivična dela protiv pravosuđa, 19) krivična dela protiv javnog reda i mira, 20) krivična dela protiv pravnog saobraćaja, 21) krivična dela protiv službene dužnosti, 22) krivična dela protiv čovečnosti i drugih dobara zaštićenih međunarodnim pravom, 23) krivična dela protiv Vojske Srbije i 24) prelazne i završne odredbe.

\footnotetext{
${ }^{13}$ Službeni glasnik RS, br. 85/2005, 88/2005, 107/2005, 72/2009, 111/2009, 121/2012, 104/2013, 108/2014 i 94/2016.

${ }^{14}$ Službeni glasnik RS, br. 85/2005.

${ }^{15}$ Službeni glasnik RS, br. 97/2008.

${ }^{16}$ Službeni glasnik RS, br. 32/2013.

${ }^{17}$ Službeni glasnik RS, br. 32/2013 i 94/2016.

${ }^{18}$ Službeni glasnik RS, br. 29/2015, 113/2017 i 41/2018.
} 
Krivični zakonik Republike Srbije u oblasti opšteg dela ne sadrži odredbe o maloletnicima kao učiniocima krivičnih dela zato što postoji poseban Zakon o maloletnim učiniocima krivičnih dela i krivičnopravnoj zaštiti maloletnih lica koji predviđa odredbe vezane za: a) krivičnopravni status maloletnika, b) vaspitne naloge, v) vaspitne mere i g) kaznu maloletničkog zatvora.

\section{Dopunski izvori}

Postoji više dopunskih izvora krivičnog prava. To su: a) normativni akti, b) međunarodni ugovori, v) običajno pravo, g) sudska praksa i d) pravna nauka.

Normativni (podzakonski) akti državnih i drugih organa predstavljaju posredni izvor krivičnog prava u slučaju „blanketnih normi“ kada krivični zakon upućuje na njihovu primenu. To su norme koje ne predviđaju sva obeležja krivičnog dela ili sankciju, već daju opšti okvir, a radi utvrđivanja osnovnih ili dopunskih obeležja tog krivičnog dela ili sankcije upućuju na podzakonski akt. Takva su krivična dela kod kojih se radnja izvršenja sastoji u „postupanju protivno propisima, odlukama ili naredbama državnih organa“ npr. krivična dela protiv: zdravlja ljudi, životne sredine, bezbednosti javnog saobraćaja ili opšte sigurnosti ljudi i imovine.

Međunarodni ugovori koji sadrže krivičnopravne odredbe se javljaju kao izvor krivičnog prava u dva vida: 1) kao neposredni izvor - međunarodni ugovor je izvor krivičnog prava kada je potpisan od strane nadležnog organa naše države, ratifikovan u Narodnoj skupštini i potom objavljen u službenom glasilu. Na taj način međunarodni ugovor dobija snagu zakona, na primer: Konvencija o nezastarevanju ratnih zločina i zločina protiv čovečnosti, Rimski statut Međunarodnog krivičnog suda i dr. i 2) kao posredni izvor - međunarodni ugovor je izvor krivičnog prava kada njegovim potpisivanjem država preuzima obavezu da takve odredbe inkorporiše u nacionalno krivično zakonodavstvo ili da krivičnom delu sadržanom u međunarodnom ugovoru obezbedi krivičnu sankciju, na primer: Konvencija o sprečavanju i kažnjavanju zločina genocida, Konvencija protiv torture i drugih surovih, nehumanih ili ponižavajućih kazni ili postupaka, Konvencija UN protiv transnacionalnog organizovanog kriminala, Evropska konvencija o suzbijanju terorizma, Krivičnopravna konvencija o korupciji, Konvencija o pranju, traženju, zapleni i konfiskaciji prihoda stečenih kriminalom i dr.

Običajno pravo kao nepisani izvor prava (ius non scriptum) je dugo vremena bio jedini regulator društvenih odnosa počev od prvobitne zajednice do pojave pisanih pravnih spomenika. Njegova primena kao izvora krivičnog prava se protivi principu zakonitosti kao najznačajnijem rukovodnom principu savremenog krivičnog prava. No, i danas se običajno pravo javlja kao izvor prava u revolucionarnim periodima kod nastajanja novih država sve dok se ne izgradi pozitivno zakonodavstvo. Takođe, u državama anglosaksonskog precedentnog prava običajno pravo (Common Law) pored sudske prakse predstavlja osnovni izvor krivičnog prava. U našoj državi gde je vladajući princip zakonitosti, običajno pravo se može javiti kao dopunski izvor krivičnog prava kod utvrđivanja značenja (tumačenja) pojedinih pojmova, naročito onih koji su regulisani uzansama, a koji mogu biti od značaja kod utvrđivanja okolnosti pod kojima je izvršeno neko krivično delo protiv imovine ili privrede, odnosno u oblasti krivičnih dela protiv čovečnosti i drugih dobara zaštićenih međunarodnim pravom (gde se pojedina međunarodna krivična dela sastoje u kršenju „zakona i običaja rata“).

Sudska praksa je od najstarijih vremena imala veliki značaj u stvaranju prava, a i danas u državama anglosaksonskog precedentnog prava uporedo sa običajnim pravom. No, i u našoj državi sudska praksa ima određeni značaj u primeni zakonskih normi. Primenjujući 
krivičnopravne propise sudovi zauzimaju pravna shvatanja o njima sa ciljem efikasnije i kvalitetnije primene pri čemu ih popunjavaju socijalnom sadržinom. Sudska primena zakonskih propisa nije mehanička, već je stvaralačka, kreativna i dinamična. Tako sudska praksa zajedno sa pravnom naukom rešavajući brojne slučajeve iz prakse: a) ima ulogu pri utvrđivanju pravog smisla pojedinih krivičnopravnih pojmova i b) stvara niz opštih pojmova i instituta: produženo krivično delo, trajno krivično delo, posredno izvršilaštvo koje je novi Krivični zakonik izričito predvideo. Pored toga najviši sud u Republici - Vrhovni kasacioni sud zauzima odgovarajuća pravna shvatanja o brojnim spornim pitanjima čime obezbeđuju jednoobraznu primenu zakona od svih nižestepenih sudova i ujednačavanje prakse.

Pravna nauka ima takođe uticaj na stvaranje i primenu krivičnog prava budući da kritikom postojećih rešenja i ukazivanjem na njihove nedostatke: a) daje predloge za njihovu izmenu i dopunu kako bi se dobila efikasnija i kvalitetnija krivičnopravna rešenja i b) ima ulogu pri tumačenju i utvrđivanju pravog smisla pojedinih opštih krivičnopravnih pojmova čime je izgrađen niz opštih pojmova i instituta: produženo krivično delo, trajno krivično delo, posredno izvršilaštvo.

\section{Uloga osnovnog i sporednog krivičnog prava}

Osnovna funkcija (uloga, cilj) krivičnog prava (osnovnog i sporednog) kao zakonskog prava jeste obavljanje zaštitne funkcije, odnosno obezbeđenje zaštite određenog društva i njegovih vrednosti od kriminaliteta. Njegov je zadatak da obezbedi postojanje jednog društva, ali i da omogući njegov dalji razvoj. Ta se zaštita ostvaruje na dva načina: a) propisivanjem koja se ljudska ponašanja smatraju krivičnim delima i b) propisivanjem krivičnih sankcija i uslova za njihovu primenu prema učiniocima takvih ponašanja. To je opšta i zajednička funkcija svakog krivičnog prava, bez obzira na konkretno društvo, odnosno državu kojoj služi kao sredstvo zaštite i nezavisno od vremenskog perioda njegovog važenja. Istovremeno tu leži i osnovna razlika između krivičnog prava raznih država.

Krivično pravo je instrument za zaštitu određenog društva i sistema njegovih zaštićenih vrednosti na određenom stepenu razvoja i kao takvo ono je specifično jer poseduje niz karakteristika po kojima se razlikuje od krivičnog prava svake druge države. Retka su krivična zakonodavstva koja izričito određuju zaštitnu funkciju ${ }^{19}$ kao što to čini Krivični zakonik Republike Srbije u članu 3. kada određuje da je cilj (funkcija, svrha) krivičnog prava zaštita čoveka i drugih osnovnih društvenih vrednosti (ne navodeći o kojim se vrednostima radi). Ovako određena funkcija predstavlja osnov za određivanje krivičnih dela, propisivanje i primenu krivičnih sankcija, i to samo u meri u kojoj je to nužno za suzbijanje tih dela. Dakle, krivično pravo ima za cilj ostvarenje dvojake funkcije: a) zaštita i obezbeđenje najznačajnijih društvenih dobara i vrednosti od njihovog povređivanja ili ugrožavanja vršenjem krivičnih dela od strane pojedinaca ili grupa, dakle očuvanje postojećih odnosa što predstavlja statičku funkciju i b) praćenje dinamike i razvoja društvenih odnosa i učešće u njihovom menjanju, unapređivanju i zaštiti što predstavlja dinamičku funkciju krivičnog prava.

Zaštitna funkcija krivičnog prava nije sveobuhvatna, već je delimična ili parcijalna. Naime, krivično pravo ne štiti sva dobra i vrednosti u jednom društvu, već samo ona koja su najvažni-

\footnotetext{
${ }^{19}$ Tako u članu 2. Krivični zakonik Ruske federacije ističe da se ova funkcija ispoljava u zaštiti od prestupničkih napada na prava i slobode čoveka i građanina, imovine, društvenog uređenja i društvene bezbednosti, oružanih snaga i ustavnog uređenja zemlje kao i obezbeđenje mira i bezbednosti čovečanstva kao i sprečavanje prestupa (I. Fedosova, T. Skuratova, Ugolovnij kodeks Rossijskoj federaciji, Moskva, 2005, str. 20).
} 
ja za pojedinca (kao čoveka i građanina) i društvo (kao zajednicu ljudi). Drugim rečima, štite se dobra i vrednosti bez kojih ne bi bilo moguće postojanje i razvoj čoveka i određenog društva. U pogledu ove zaštite razlikuju se dve vrste vrednosti: a) društvene vrednosti i dobra do čijeg očuvanja je određenoj društvenoj zajednici (vladajućoj strukturi) naročito stalo i b) društvene vrednosti i dobra koja imaju univerzalni, opštecivilizacijski značaj, koja se dakle štite u svim društvima i svim periodima razvoja bez obzira na oblik društvene organizacije. Ali, čak ni ovim dobrima i vrednostima krivično pravo ne pruža potpunu, već nepotpunu, parcijalnu zaštitu, tj. zaštitu koja ima fragmentarni karakter. Ono se ograničava na zaštitu ovih dobara i vrednosti samo od određenih napada u vidu povrede i ugrožavanja koja su zakonom propisana kao krivična dela. Ovako određena zaštitna funkcija krivičnom pravu daje utilitaristički karakter. No, ona se pojavljuje i kao značajan instrument samoograničavanja države.

Ovakva delimična, fragmentarna zaštita je ne samo opravdana, već i jedino moguća, jer bi sveobuhvatna i totalna zaštita dovela do negacije slobode i onemogućavanja njenog razvoja, kao i razvoja društva u celini, što bi značilo negaciju svrhe zaštite. Zaštita ovih društvenih vrednosti ne ostvaruje se samo putem krivičnog prava, već i putem drugih grana prava, tj. celim pravnim sistemom, pri čemu ova zaštita ima opštiji i primarni karakter za razliku od krivičnopravne zaštite koja ima specijalni, sekundarni, subsidijarni karakter. Mehanizam krivičnopravne zaštite određenih društvenih vrednosti stupa u dejstvo tek kada se utvrdi da je mehanizam zaštite neke druge grane prava nedovoljan da obezbedi očuvanje tih dobara ili vrednosti. U tom smislu se ono pojavljuje kao ultima ratio pravnog poretka, kao njegov poslednji i najvažniji čuvar. ${ }^{20}$

lako se krivičnopravna zaštita društvenih vrednosti ostvaruje uglavnom kroz kaznu kao najvažniju krivičnu sankciju usled čega joj se daje represivni, retributivni karakter, ona se ne ostvaruje samo kroz retribuciju i odmazdu, već i kroz prevenciju (sprečavanje) vršenja krivičnih dela. Šta više cilj je krivičnog prava da vaspitno utiče na ponašanje ljudi (kroz jačanje morala i učvršćivanje obaveze poštovanja zakona) kako bi se oni uzdržali od kršenja propisa i vršenja krivičnih dela. Funkcija našeg krivičnog prava je zaštita najznačajnijih društvenih dobara i vrednosti „zaštićenih“ krivičnim zakonodavstvom. Ova se zaštita ostvaruje na specifičan način. Naime, krivično pravo ne reguliše društvene odnose neposredno, tj. ono ne propisuje pravila ponašanja, već određuje sankcije za nepoštovanje postojećih društvenih, a pre svega pravnih pravila ponašanja. Drugim rečima, zaštita navedenih vrednosti ostvaruje se na taj način što se određuju ljudska ponašanja koja predstavljaju krivična dela i što se za takva ponašanja propisuju krivične sankcije prema njihovim učiniocima u cilju suzbijanja kriminaliteta. Dakle, krivičnopravna zaštita ostvaruje se post factum, onda kada je zaštićeno dobro već povređeno ili ugroženo. Zbog te činjenice izgleda da zaštitna funkcija, koja se najčešće ostvaruje primenom kazne, ima čisto represivni karakter. Kroz kaznu se, pored represije, ostvaruje i prevencija, i to kako individualna, tako i generalna.

\section{Mesto sporednog krivičnog prava}

Već smo videli da se materijalno (supstancijalno) krivično pravo može podeliti na: 1) opšte ${ }^{21}$ i 2) posebno pri čemu su ova dva dela uzajamno povezana i međusobno uslovljena. Ova deoba

\footnotetext{
${ }^{20}$ Ž. Horvatić, Krivično pravo, Opći dio, Beograd, 2003, str. 31-32.

${ }^{21}$ U pravnoj teoriji se mogu naći shvatanja prema kojima "opšte" krivično pravo znači pravo koje se odnosi na sve građane bez izuzetaka, dok je "posebno" pravo ono koje se odnosi na posebne kategorije lica: maloletnike, vojna lica (G. Marjanovik, Makedonsko krivično pravo, Opšt del, op. cit. str. 7 ili V. Grozdanić, M. Škorić, Uvod u kazneno pravo,
} 
ima osnova u strukturi savremenih krivičnih zakona ili zakonika. U oba slučaja se radi o redovnoj primeni krivičnog prava. To je tzv. redovno krivično pravo koje se primenjuje po pravilu, običajeno u doba mira, u redovnim, normalnim okolnostima, nasuprot vanrednom krivičnom pravu.

Zavisno od izvora, nacionalno (interno) krivično pravo može da bude: 1) osnovno i 2) sporedno, pomoćno ili dopunsko. Ovo dopunsko, pomoćno ili sporedno krivično pravo čine krivičnopravne odredbe sadržane u drugim zakonima koji uređuju odnose u drugim oblastima prava. Ono nije manjeg značaja u odnosu na osnovno krivično pravo kako bi se to moglo zaključiti na osnovu tumačenja njegovog naziva. Taj naziv samo govori da se ovde ne radi o propisima koji su sadržane u Krivičnom zakon(ik)u kao osnovnom pravnom aktu i izvoru krivičnog prava. lako Krivični zakonik po pravilu obuhvata celokupnu materiju krivičnog prava, neke zakonske odredbe koje su po svojoj prirodi krivičnopravne odredbe nisu unete iz praktičnih ili nomotehničkih razloga u Krivični zakonik kao celinu, već se nalaze u nekim drugim zakonima ${ }^{22}$ koji se odnose na različite oblasti pravnog regulisanja zbog toga što su po svojoj prirodi tesno povezani sa tom materijom. Ovde se dakle radi o krivičnopravnim odredbama koje se nalaze izvan Krivičnog zakonika. ${ }^{23}$

Drugim rečima, sporedno krivično pravo („stranska kazenskega zakonodaja“) označava primere kada krivično delo nije propisano u posebnom delu Krivičnog zakonika ili drugom krivičnopravnom propisu, već u zakonu iz drugog pravnog područja. Ono je tako namenjeno uređenju razmera u drugim pravnim područjima gde se na krivičnopravni način uređuju opisi krivičnih dela i propisuju krivične sankcije za njihove učinioce. Oni ne sadrže odredbe opšteg karaktera, već samo odredbe posebnog dela - opise krivičnih dela. ${ }^{24}$

Postojanje tzv. „izvankodifikacijskih“ inkriminacija u okviru sporednog krivičnog prava opravdavaju različiti razlozi, među kojima se po svom značaju ističu dva razloga. Pre svega, Krivični zakonik spada u trajnije zakone čija procedura donošenja i njegova izmena i dopuna traje duže vreme i izaziva širu pažnju opšte javnosti. Takođe nije preporučljivo da se u ovakav zakonski tekst unose sve inkriminacije, posebne one koje se odnose na dinamične segmente društva što nalaže njihovo često i brzo menjanje kako bi se takve norme prilagodile realnim društvenim odnosima. Pored toga, nekada je zbog specifičnosti materije koja se reguliše sporednim zakonima bolje da takva krivična dela budu u sporednim zakonima jer je za njihovo razumevanje često potrebno poznavanje celovitosti takvih zakona. Zakoni u oblasti sporednog krivičnog prava kao krivična dela predviđaju samo ona ponašanja kojima se krše određene odredbe tih zakona, pa je ta sadržajna veza sa tim zakonom glavni razlog zašto te odredbe i nisu unete u Krivični zakonik. Najčešće su ova krivična dela i propisana kao blanketna krivična dela tj. u njima je propisana kazna za postupanje protivno nekim (ili svim) odredbama takvog zakona. ${ }^{25}$

Pri tome naravno treba imati na umu da nekontrolisano širenje sporednog krivičnog zakonodavstva predstavlja ozbiljnu opasnost za integritet i celovitost krivičnog zakonodavstva, posebno garantivnu funkciju krivičnog prava. To bi moglo da ugrozi i osnovne fundamentalne

Opći dio, op. cit. str. 5). No, uobičajeno je da opšte krivično pravo sadrži odredbe koje važe za sva krivična dela. Njima se uređuju pretpostavke kažnjivosti i krivičnih sankcija, dok posebni deo sadrži samo opise pojedinih krivičnih dela i kazne koje se mogu izreći njihovim učiniocima (P. Novoselec, Opći dio kaznenog prava, op. cit. str. 4).

${ }^{22}$ M. Radovanović, Krivično pravo, Opšti deo, Beograd, 1975, str. 109.

${ }^{23}$ M. Đorđević, Đ. Đorđević, Krivično pravo, Beograd, 2016, str. 25.

${ }^{24}$ Lj. Selinšek, Kazensko pravo, Ljubljana, 2007, str. 58.

${ }^{25}$ B. Pavišić, V. Grozdanić, P. Veić, Komentar Kaznenog zakona, Zagreb, 2007, str. 28. 
principe na kojima počiva krivično pravo uopšte jer bi se na zaobilazan način ovi principi osnovnog krivičnog zakonodavstva napuštali. To bi moglo da vodi ka dezintegraciji krivičnog prava, njegovog derogiranja, pa i delimičnog ukidanja jer bi se putem sporednog krivičnog zakonodavstva posebni deo koji predstavlja u suštini pravo merilo širine krivičnopravne represije mogao dobrim delom staviti van primene jer bi ga suspendovali ti sporedni zakoni. Ovakvo sporedno pravo se inače još naziv i „temporalno ili ministarsko pravo“ jer se donosi u suštini u funkciji „dnevne politike“ za određeno, kraće vreme sa ciljem postizanja kratkoročnih ciljeva pojedini struktura vlasti. Ovo pravo nije karakteristika stabilnih i demokratskih društava. ${ }^{26}$

Odnos sporednog i osnovnog krivičnog prava je višestruk. Prvo, norme osnovnog krivičnog prava (posebno njegovog opšteg dela) se jedinstveno primenjuju na sve učinioce krivičnih dela bez obzira da li su takva dela propisana u posebnom delu osnovnog Krivičnog zakon(ik)a ili u nekom pomoćnom, sporednom zakonu. To izričito proizilazi iz odredbe čl. 13. KZ prema kojoj odredbe opšteg dela Krivičnog zakonika važe za sva krivična dela određena ovim zakonikom ili "drugim“ (podrazumeva se sporednim zakonom).

Ali i pri propisivanju krivičnih sela u sporednom zakonu zakonodavac u svemu mora da se pridržava pravila i granica sadržanih u odredbama opšteg dela Krivičnog zakonika. I ovde krivično delo mora biti propisano jasno i precizno sa svim elementima posebnog bića. Kao radnja izvršenja najčešće se određuje postupanje upravo protivno tom zakonu (u čijim okvirima je takvo krivično delo i predviđao), a vrsta i mera kazne i druge krivične sankcije mora da se kreće u okvirima koji su određeni sistemom krivičnih sankcija sadržanim u Krivičnom zakonu.

Po pravilu, brojna krivična dela u sferi privrednog, ekološkog, bankarskog, kompjuterskog kriminaliteta koji predstavlja obeležje savremenog kriminaliteta su najčešće prvo i bila propisana u sporednim zakonima, dakle u zakonima koji su uređivali te određene oblasti društvenog života. A tek kasnije, pri kodifikaciji, takve odredbe su unošene iz sporednog u osnovno krivično zakonodavstvo (kao što je to bio slučaj sa krivičnim delima iz Zakona o oružju i municiji, Zakona o javnom redu i miru, Zakona o poreskom postupku i poreskoj administraciji, Carinskog zakona, Zakona o sprečavanju pranja novca, Zakona o sprečavanju nasilja i nedoličnog ponašanja na sportskim takmičenjima i sl.).

Ipak ne treba priznavati preveliki značaj tom sporednom krivičnom pravu jer se na taj način može umanjiti (doduše na posredan način) i značaj Krivičnog zakonika kao temeljnog propisa koji teži što široj kodifikaciji. Kodifikacija krivičnog prava osim opštih prednosti koje donosi svaka kodifikacija (sistemski poredak pravnih normi iz jedne oblasti prava) ima i tu prednost da svakom pojedincu olakšava uvid u ona ponašanja koja su zabranjena i kažnjiva i na taj način i omogućava spoznaju o granicama vlastite slobode. ${ }^{27}$ To ima ulogu i kod primene principa pravičnosti, odnosno principa krivice koji se nalazi u osnovi subjektivne krivične odgovornosti. Naime, kao jedna od važnih pretpostavki za postojanje krivice (a time i samog krivičnog dela čiji je konstitutivni elemenat formalnog karaktera upravo krivica) jeste svest, odnosno dužnost i mogućnost postojanja svesti na strani učinioca krivičnog dela o protivpravnosti učinjenog dela u vreme preduzimanja radnje izvršenja. Ako nema ove svesti ili mogućnosti postojanja svesti na strani učinioca da zna koja su ponašanja zabranjena, odnosno ako se nalazi u opravdanoj pravnoj zabludi, njegove krivice nema, pa time ni primene krivičnih sankcija za prouzrokovanu posledicu u spoljnom svetu. Sporedno krivično pravo u uređenom pravnom si-

\footnotetext{
${ }^{26}$ D. Jovašević, Lj. Mitrović, V. Ikanović, Krivično pravo Republike Srpske, Opšti dio, Banja Luka, 2017, str. 74.

${ }^{27}$ M. Simović, D. Jovašević, Leksikon krivičnog prava Bosne i Hercegovine, Sarajevo, 2018, str. 389-391.
} 
stemu treba da predstavlja izuzetak, a ne pravilo jer je zbog pravne sigurnosti građana veoma važno da krivičnopravne norme budu sistematizovane na jednom mestu, u jednom pravnom aktu, a ne da su rasute u više zakona, koji se povrh toga često i menjaju. ${ }^{28}$

\section{Zaključak}

Krivično pravo kao skup zakonskih pravnih propisa kojima se određuju krivična dela i krivične sankcije za njihove učinioce treba da ostvari određeni cilj, ulogu - a to je suzbijanje i sprečavanje vršenja krivičnih dela kojima se povređuju ili ugrožavaju zaštićene vrednosti, interesi i dobra. Iz ove definicije proizilazi da je krivično pravo sistem zakonskih propisa, a da je njegov osnovni formalni izvor zakon. Pored osnovnog krivičnog prava koje je sadržano u Krivičnom zakoniku, savremena društva karakteriše i postojanje sporednog, dopunskog ili pomoćnog krivičnog prava. Sporedno, pomoćno ili dopunsko čine krivičnopravne odredbe sadržane u drugim zakonima koji uređuju odnose u drugim oblastima prava. lako Krivični zakonik po pravilu obuhvata celokupnu materiju krivičnog prava, neke zakonske odredbe koje su po svojoj prirodi krivičnopravne odredbe nisu unete iz praktičnih ili nomotehničkih razloga u Krivični zakonik kao celinu, već se nalaze u nekim drugim zakonima koji se odnose na različite oblasti pravnog regulisanja zbog toga što su po svojoj prirodi tesno povezani sa tom materijom. Ovde se dakle radi o krivičnopravnim odredbama koje se nalaze izvan Krivičnog zakonika.

Postojanje tzv. „izvankodifikacijskih“ inkriminacija u okviru sporednog krivičnog prava opravdavaju različiti razlozi, među kojima se po svom značaju ističu dva razloga. Pre svega, Krivični zakonik spada u trajnije zakone čija procedura donošenja i njegova izmena i dopuna traje duže vreme i izaziva širu pažnju opšte javnosti. Takođe nije preporučljivo da se u ovakav zakonski tekst unose sve inkriminacije, posebne one koje se odnose na dinamične segmente društva što nalaže njihovo često i brzo menjanje kako bi se takve norme prilagodile realnim društvenim odnosima. Pored toga, nekada je zbog specifičnosti materije koja se reguliše sporednim zakonima bolje da takva krivična dela budu u sporednim zakonima jer je za njihovo razumevanje često potrebno poznavanje celovitosti takvih zakona. Zakoni u oblasti sporednog krivičnog prava kao krivična dela predviđaju samo ona ponašanja kojima se krše određene odredbe tih zakona, pa je ta sadržajna veza sa tim zakonom glavni razlog zašto te odredbe i nisu unete u Krivični zakonik. Najčešće su ova krivična dela i propisana kao blanketna krivična dela tj. u njima je propisana kazna za postupanje protivno nekim (ili svim) odredbama takvog zakona.

Pri tome naravno treba imati na umu da nekontrolisano širenje sporednog krivičnog zakonodavstva predstavlja ozbiljnu opasnost za integritet i celovitost krivičnog zakonodavstva, posebno garantivnu funkciju krivičnog prava. To bi moglo da ugrozi i osnovne fundamentalne principe na kojima počiva krivično pravo uopšte jer bi se na zaobilazan način ovi principi osnovnog krivičnog zakonodavstva napuštali. To bi moglo da vodi ka dezintegraciji krivičnog prava, njegovog derogiranja, pa i delimičnog ukidanja jer bi se putem sporednog krivičnog zakonodavstva posebni deo koji predstavlja u suštini pravo merilo širine krivičnopravne represije mogao dobrim delom staviti van primene jer bi ga suspendovali ti sporedni zakoni. Ovakvo

\footnotetext{
${ }^{28}$ N. Mrvić Petrović, Krivično pravo, Beograd, 2005, str. 45.
} 
sporedno pravo se inače još naziv i „temporalno ili ministarsko pravo“ jer se donosi u suštini u funkciji „dnevne politike“ za određeno, kraće vreme sa ciljem postizanja kratkoročnih ciljeva pojedini struktura vlasti. Ovo pravo nije karakteristika stabilnih i demokratskih društava.

Po pravilu, brojna krivična dela u sferi privrednog, ekološkog, bankarskog, kompjuterskog kriminaliteta koji predstavlja obeležje savremenog kriminaliteta su najčešće prvo i bila propisana u sporednim zakonima, dakle u zakonima koji su uređivali te određene oblasti društvenog života. A tek kasnije, pri kodifikaciji, takve odredbe su unošene iz sporednog u osnovno krivično zakonodavstvo (kao što je to bio slučaj sa krivičnim delima iz Zakona o oružju i municiji, Zakona o javnom redu i miru, Zakona o poreskom postupku i poreskoj administraciji, Carinskog zakona, Zakona o sprečavanju pranja novca, Zakona o sprečavanju nasilja i nedoličnog ponašanja na sportskim takmičenjima i sl.).

\section{Literatura}

[1] Grozdanić, V., Škorić, M., Uvod u kazneno pravo, Opći dio, Rijeka, 2009.

[2] Đorđević, M., Đorđević, Đ., Krivično pravo, Beograd, 2016.

[3] Zlatarić, B., Krivično pravo, Opći dio, Zagreb, 1977.

[4] Jovašević, D., Leksikon krivičnog prava, Beograd, 2011.

[5] Jovašević, D., Mitrović, Lj., Ikanović, V., Krivično pravo Republike Srpske, Opšti dio, Banja Luka, 2017.

[6] Jovašević, D., Krivično pravo, Opšti deo, Beograd, 2018. 2004.

[7] Lazarević, Lj., Vučković, B., Vučković, V., Komentar Krivičnog zakonika Crne Gore, Cetinje,

[8] Marjanovik, G., Makedonsko krivično pravo, Opšt del, Skopje, 1998.

[9] Mrvić Petrović, N., Krivično pravo, Beograd, 2005.

[10] Novoselec, P., Opći dio kaznenog prava, Zagreb, 2004.

[11] Pavišić, B., Grozdanić, V., Veić, P., Komentar Kaznenog zakona, Zagreb, 2007.

[12] Petrović, B., Jovašević, D., Ferhatović, A., Krivično pravo 1, Sarajevo, 2015.

[13] Radovanović, M., Krivično pravo, Opšti deo, Beograd, 1975.

[14] Selinšek, Lj., Kazensko pravo, Ljubljana, 2007.

[15] Simović, M., Jovašević, D., Leksikon krivičnog prava Bosne i Hercegovine, Sarajevo, 2018.

[16] Službeni glasnik RS, br. 85/2005, 88/2005, 107/2005, 72/2009, 111/2009, 121/2012, 104/2013, 108/2014 i 94/2016.

[17] Službeni glasnik RS, br. 85/2005.

[18] Službeni glasnik RS, br. 98/2006.

[19] Službeni glasnik RS, br. 97/2008.

[20] Službeni glasnik RS, br. 32/2013.

[21] Službeni glasnik RS, br. 32/2013 i 94/2016.

[22] Službeni glasnik RS, br. 29/2015, 113/2017 i 41/2018.

[23] Fedosova, I., Skuratova, T., Ugolovnij kodeks Rossijskoj federaciji, Moskva, 2005.

[24] Horvatić, Ž., Kazneno pravo, Opći dio, Zagreb, 2003.

[25] Welzel, N., Das Deutsche Strafrecht, Berlin, 1960. 